\title{
COMPARISON OF SELECTED NATIONAL HEALTHCARE SYSTEMS' EFFICIENCY
}

\author{
MAREK BIERNACKI \\ Wrocław University of Economics, Faculty of Management, Computer Science and Finance, \\ Department of Mathematics and Cybernetics, Komandorska 118/120, 53-345 Wrocław, Poland \\ email: marek.biernacki@ue.wroc.pl
}

\begin{abstract}
The efficiency of selected national healthcare systems in the European Union was analyzed with Eurostat from 2004 to 2013 data, in particular considering countries which made a transition after 1990. The analysis of efficiency was performed using DEA-a nonparametric method implemented in MaxDEA 6.3.mdb software. Estonia, Hungary and Slovakia improved their efficiency of medical treatment, Poland and the Czech Republic deteriorated, while effectiveness of medical treatment measured by HLY improved in the Czech Republic and deteriorated in Poland in the period under study. Among the transition economies after 1990, Poland's healthcare system was most efficient as a result of healthy population and relatively low financial inputs to healthcare. It is worth emphasizing that when life expectancy is above the trend line, then people in those countries live longer, whereas if infant mortality is below the trend line, it shows that obstetrical care in those countries is excellent.
\end{abstract}

Key words: health care system, efficiency, DEA

JEL Codes: I13, I18, O57

\section{DOI: 10.15611/amse.2017.20.01}

\section{Introduction}

The paper aims at analyzing the efficiency of national healthcare systems in European countries, considering in particular the transition countries after 1990. The scope of this article is the treatment efficiency analysis in the middle-east (post-Communist) countries. Those countries has to choose (based on benchmarking) the most optimal financing system powered by the best known systems. The structure of the article is: Review of health data that describes national healthcare systems in the analyzed and chosen European countries in 2004 and 2013. And then with the DEA method those countries treatment methods were evaluated and the recommendations were proposed for the particular countries. DEA method results can be confronted with the country placement being above or under following dependencies trend line: GDP (USD PPP) per capita vs. life expectancy and GDP (USD PPP) per capita vs. infant mortality (Fig. 2 and 3).

Modern healthcare systems operate in an unstable environment resulting from the following social transition factors:

Demographic changes (aging societies),

Fast pace of technological innovations,

Changing (more demanding) expectations of patients and society,

Increased costs as a consequence of previous factors.

Therefore the efficiency of entire system and of specific medical institutions should be optimized so as to meet the social expectations. The member states of the European Union use 
the two basic systems of financing healthcare. First, Bismarck insurance system is derived from solutions adopted by sickness insurance law initiated by Otto von Bismarck in 1883. It provided for compulsory participation by all industrial wage earners. The cost of the insurance was divided between employers and the employed, the workers were protected from consequences of random events such as the loss of material safety of workers' families [Kautsch M., Klich J., Whitfeld M. (2001)].

The Beveridge model was introduced in 1948 in the United Kingdom and excluded medical care from the 1911 social insurance system. Medical care is provided and financed by the government through general taxes. Thus the healthcare system monopolized by the state provided health services to all citizens. Figure 1 shows how Bismarck and Beveridge systems are implemented in selected countries of the European Union.

Figure 1: Healthcare systems and their financing in selected countries

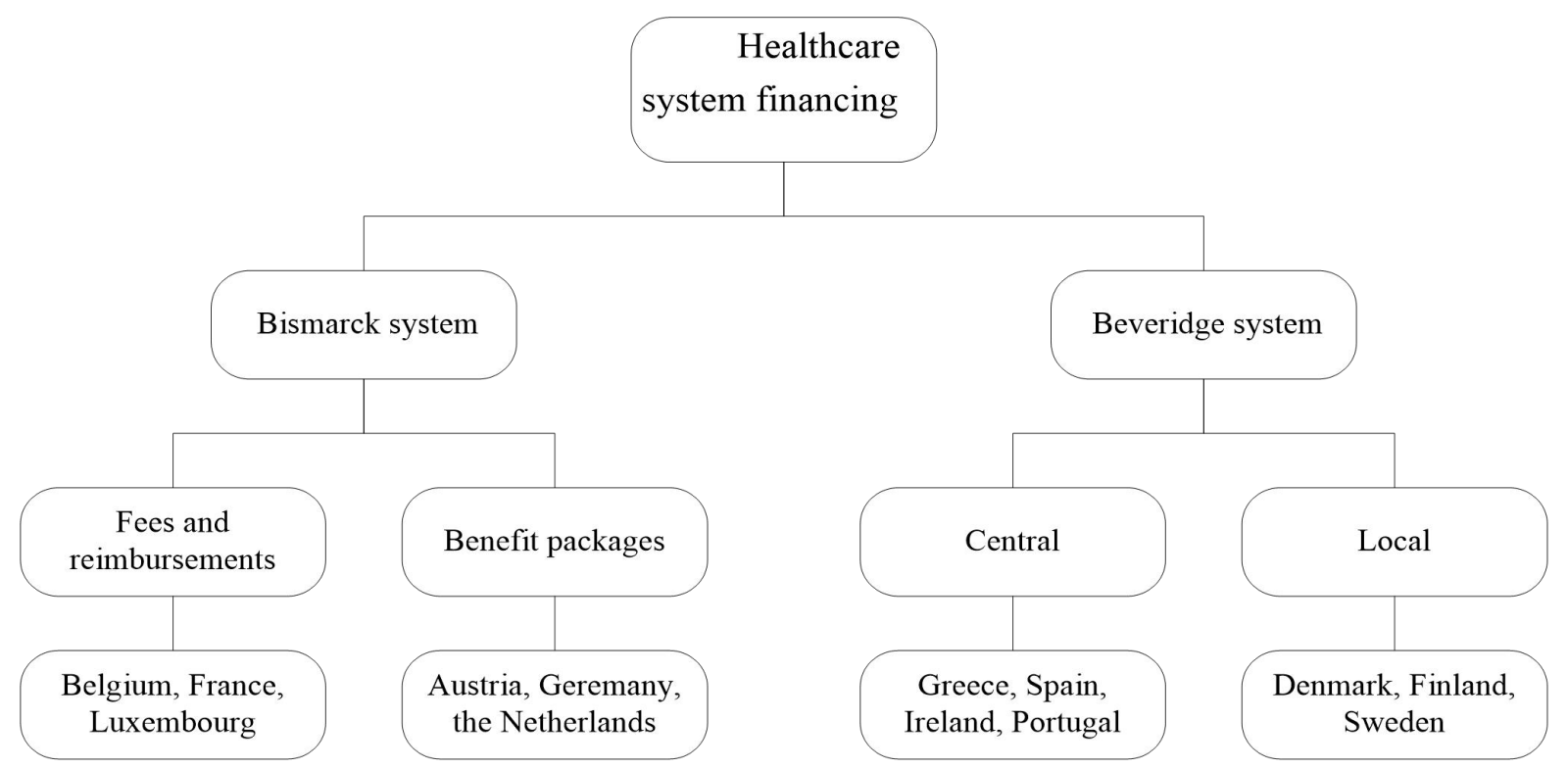

Source: Niżnik J., 2004

\section{Description of selected national healthcare systems}

To analyze the efficiency of European national healthcare systems empirical data published by Eurostat in 2004 and 2013 were employed. As inputs to the process the following variables were assumed: national health expenditure (\% GDP), GDP (purchasing power parity) per capita (PPP), the number of physicians per 100 thousand inhabitants (Phys), and the number of beds per 100 thousand inhabitants. The outputs of the process are: deaths (in thousands) caused respectively by cancers and by cardiovascular diseases (CVD) per 100 thousand inhabitants, life expectancy (E), and an average healthy life years (HLY); see tables 1 and 2. The countries which made economic transition in the 1990. and adopted a Bismarck system of financing healthcare, i.e. the Czech Republic, Hungary, Poland, Slovakia will be analyzed in more detail.

Indicators with regard to financing system are given in columns 1 and 2. The OECD countries are characterized by a large variance of wealth as shown by data in column 2: GDP (USD PPP) per capita, resulting in a large variance of healthcare financing as shown by data in column 1. Columns 3 and 4 represent current conditions of healthcare system: numbers of physicians and beds per 100 thousand inhabitants. The number of beds in richer countries 
tends to decline as a result of introducing the most recent technologies to medical treatment, which shorten significantly inpatient stays.

Table 1: Selected descriptive data of national healthcare systems, 2004

\begin{tabular}{|c|c|c|c|c|c|c|c|c|}
\hline Country & \%GDP & PPP & Phys & Beds & Cancers & CVD & $\mathbf{E}$ & HLY \\
\hline$(\mathrm{BC}, \mathrm{r})$ Austria & 10.43 & 3436.30 & 420.27 & 773.69 & 171.25 & 249.63 & 79.44 & 59.15 \\
\hline$(\mathrm{BC}, \mathrm{o})$ Belgium & 9.68 & 3022.38 & 286.83 & 747.34 & 173.87 & 207.62 & 79.12 & 62.35 \\
\hline (BCR) Bulgaria & 7.31 & 646.75 & 352.21 & 613.13 & 156.53 & 685.35 & 72.60 & 67.00 \\
\hline$(B V, c)$ Cyprus & 6.42 & 1509.63 & 268.39 & 420.00 & 120.60 & 230.28 & 79.71 & 59.00 \\
\hline (BCR) Czech Republic & 6.90 & 1387.30 & 351.79 & 764.23 & 230.01 & 430.53 & 75.96 & 59.00 \\
\hline$(\mathrm{BV}, \mathrm{l})$ Denmark & 9.67 & 3126.04 & 322.24 & 397.36 & 208.16 & 217.18 & 77.98 & 68.40 \\
\hline (BCR) Estonia & 5.13 & 749.06 & 321.28 & 569.93 & 198.08 & 515.38 & 72.29 & 50.35 \\
\hline$(B V, 1)$ Finland & 8.21 & 2454.79 & 259.04 & 709.94 & 143.81 & 248.37 & 78.99 & 52.10 \\
\hline$(\mathrm{BC}, \mathrm{r})$ Germany & 10.67 & 3164.39 & 339.05 & 857.93 & 169.81 & 262.82 & 79.36 & 54.65 \\
\hline$(\mathrm{BV}, \mathrm{c})$ Greece & 8.68 & 2094.09 & 487.65 & 468.92 & 162.01 & 314.41 & 79.04 & 66.65 \\
\hline (BCR) Hungary & 8.22 & 1328.73 & 333.69 & 788.77 & 260.77 & 486.95 & 73.03 & 53.25 \\
\hline$(\mathrm{BC}+\mathrm{BV})$ Latvia & 6.51 & 774.46 & 291.77 & 791.43 & 196.74 & 593.9 & 70.97 & 52.00 \\
\hline$(\mathrm{BCR}+\mathrm{BV})$ Lithuania & 5.67 & 747.01 & 362.65 & 756.60 & 193.84 & 524.97 & 72.05 & 53.00 \\
\hline$(\mathrm{BC}, \mathrm{o})$ Luxembourg & 8.20 & 5372.78 & 242.30 & 639.37 & 160.49 & 222.93 & 80.04 & 62.35 \\
\hline$(\mathrm{BC}, \mathrm{c})$ Netherlands & 9.97 & 3311.33 & 264.78 & 447.15 & 191.21 & 197.38 & 79.42 & 64.45 \\
\hline (BCR) Poland & 6.20 & 806.55 & 229.02 & 666.84 & 213.98 & 397.03 & 74.99 & 64.05 \\
\hline$(\mathrm{BV}, \mathrm{c})$ Portugal & 10.05 & 1999.67 & 328.28 & 358.91 & 154.63 & 223.83 & 78.44 & 57.85 \\
\hline (BCR) Slovakia & 7.21 & 1058.44 & 314.55 & 689.51 & 207.71 & 501.04 & 74.38 & 55.90 \\
\hline (BCR) Slovenia & 8.47 & 1885.35 & 229.79 & 479.92 & 198.81 & 276.99 & 77.32 & 58.25 \\
\hline$(B V, c)$ Spain & 8.22 & 2139.63 & 346.28 & 341.70 & 164.21 & 173.54 & 80.46 & 63.35 \\
\hline$(B V, 1)$ Sweden & 9.09 & 2957.95 & 344.76 & 301.19 & 155.59 & 218.79 & 80.55 & 63.85 \\
\hline (BV) UK & 7.91 & 2536.23 & 231.34 & 386.66 & 183.20 & 223.96 & 79.03 & 64.85 \\
\hline
\end{tabular}

Source: Eurostat ec.europa.eu/eurostat/statistics-explained/.../Healthcare_statistics

Note: BC, o- Bismarck system, fees and reimbursement; BC, $r$ - Bismarck system, benefit packages; BV, cBeveridge central system; BV, 1 - Beveridge local system; BCR - Bismarck system in transition countries following reforms of 1990 .

Figure 2 reveals that countries under study are below the trend line, which implies that the life expectancy in such a country should be larger, at least in the trend line. Figure 3 represents the relationship between infant mortality and GDP per capita. The countries of our 
interest also are below the trend line, but as mortality is a depressant, such results indicate that the healthcare in those countries is fine.

Table 2: Selected descriptive data of national healthcare systems, 2013

\begin{tabular}{|c|c|c|c|c|c|c|c|c|}
\hline Country & \%GDP & PPP & Phys & Beds & Cancers & CVD & $\mathbf{E}$ & HLY \\
\hline Austria & 11.03 & 4884.62 & 499.01 & 764.70 & 150.23 & 197.92 & 81.40 & 60.00 \\
\hline Belgium & 11.19 & 4526.08 & 295.20 & 625.67 & 159.00 & 146.61 & 80.51 & 63.90 \\
\hline Bulgaria & 7.63 & 1212.52 & 397.67 & 681.64 & 166.99 & 574.47 & 74.44 & 64.50 \\
\hline Cyprus & 7.44 & 2196.98 & 322.20 & 341.69 & 119.10 & 184.83 & 81.77 & 64.70 \\
\hline Czech Republic & 7.24 & 1981.84 & 368.92 & 645.89 & 178.80 & 309.72 & 78.40 & 63.40 \\
\hline Denmark & 10.62 & 4552.4 & 362.44 & 307.39 & 185.35 & 135.85 & 80.39 & 59.80 \\
\hline Estonia & 5.72 & 1452.64 & 328.30 & 500.53 & 186.45 & 369.24 & 76.63 & 55.50 \\
\hline Finland & 9.40 & 3604.12 & 301.71 & 485.93 & 133.11 & 187.11 & 81.24 & 56.80 \\
\hline Germany & 11.30 & 4811.82 & 405.41 & 827.77 & 158.63 & 107.15 & 80.71 & 57.40 \\
\hline Greece & 9.82 & 2512.67 & 623.11 & 475.87 & 157.02 & 199.75 & 80.82 & 64.90 \\
\hline Hungary & 8.05 & 1839.01 & 320.91 & 703.73 & 152.68 & 217.55 & 75.81 & 59.60 \\
\hline Latvia & 5.72 & 1310.4 & 319.13 & 579.98 & 232.62 & 387.05 & 74.13 & 53.00 \\
\hline Lithuania & 6.24 & 1578.73 & 427.70 & 728.20 & 194.52 & 470.50 & 74.16 & 59.20 \\
\hline Luxembourg & 7.10 & 6518.22 & 280.66 & 505.37 & 182.16 & 451.08 & 82.72 & 63.40 \\
\hline Poland & 6.66 & 1550.72 & 221.40 & 650.04 & 169.97 & 133.01 & 77.26 & 61.00 \\
\hline Portugal & 9.71 & 2507.79 & 426.07 & 339.50 & 187.00 & 314.62 & 80.97 & 63.10 \\
\hline Slovakia & 8.21 & 2146.56 & 342.80 & 580.34 & 151.23 & 143.90 & 75.66 & 54.40 \\
\hline Slovenia & 9.16 & 2595.21 & 263.03 & 455.39 & 182.18 & 507.85 & 79.96 & 58.60 \\
\hline Spain & 8.88 & 2845.70 & 381.31 & 296.51 & 195.99 & 218.40 & 83.22 & 64.30 \\
\hline Sweden & 9.71 & 4243.84 & 411.70 & 259.42 & 147.01 & 122.44 & 82.11 & 66.50 \\
\hline UK & 9.12 & 3310.70 & 277.96 & 276.64 & 165.80 & 140.73 & 81.16 & 64.60 \\
\hline
\end{tabular}

Source: Eurostat ec.europa.eu/eurostat/statistics-explained/.../Healthcare_statistics

\section{Analyzing the efficiency of healthcare systems by DEA}

A nonparametric method DEA was used to assess the efficiency. DEA employs linear models with objective function given by Debreu-Farrell technical efficiency measure [Charnes A., Cooper W., Rhodes E]. The efficiency of healthcare system implies that we want to minimize cost subject to required outputs, hence we adopt an input oriented model. The computations were performed using the MasDEA 6.3.mdb software, and the results are presented in table 3.

Column 1 (Score) shows the values of Farrell technical efficiency measure; model is inputoriented and based on constant returns to scale (CCR). The following columns present inputs and outputs of a virtual DMU obtained as a linear combination efficient countries, i.e. Cyprus, 
Luxembourg and the United Kingdom. The results from table 3 will be explained for the case of Austria (row 1).

In order to reach best inputs producing the same outputs, current (real) quantities of inputs should be reduced by $(1-0.612) \times 100 \%=38.8 \%$, as indicated by efficiency measure. In real terms (see table 4), it means the proportional reduction: of GDP by $4.04 \%$, of the number of physicians by 162.94 , and of the number of beds by 297.97 per 100 thousand of inhabitants (proportionate movement). Next, the target value for the number of beds is reduced by the slack improvement value, i.e. by 54.4 beds (slack movement of inputs). Given target best values of inputs, the values of outputs are maintained, with some of them even improved: Cancers by 0.298 and CVD by 0.012 (slack movements of outputs), i.e. mortality caused by cancers and by cardiovascular diseases can be lessened, thus obtaining the so-called ideal outputs.

Figure 2: GDP (USD PPP) per capita vs. life expectancy in the OECD countries, 2005.

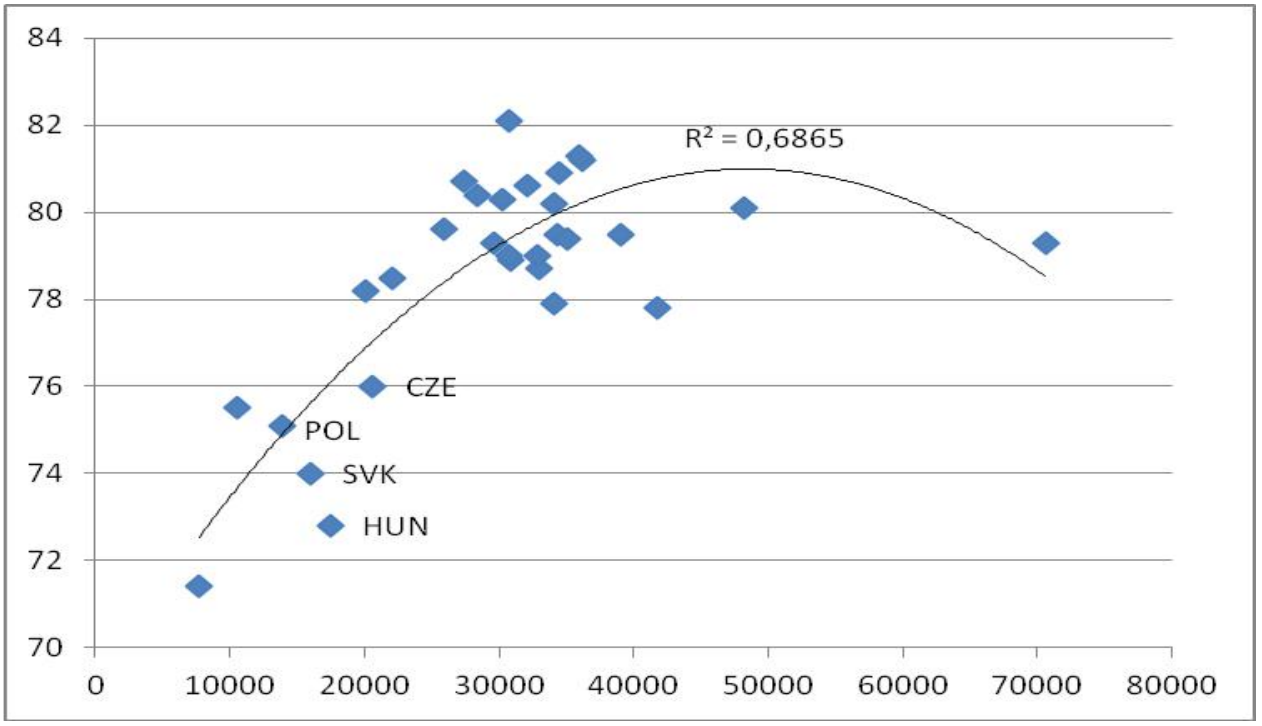

Source: modified from Leigh A., Jencks Ch., Smeeding T. (2009).

Figure 3: GDP (USD PPP) per capita vs. infant mortality in the OECD countries, 2005

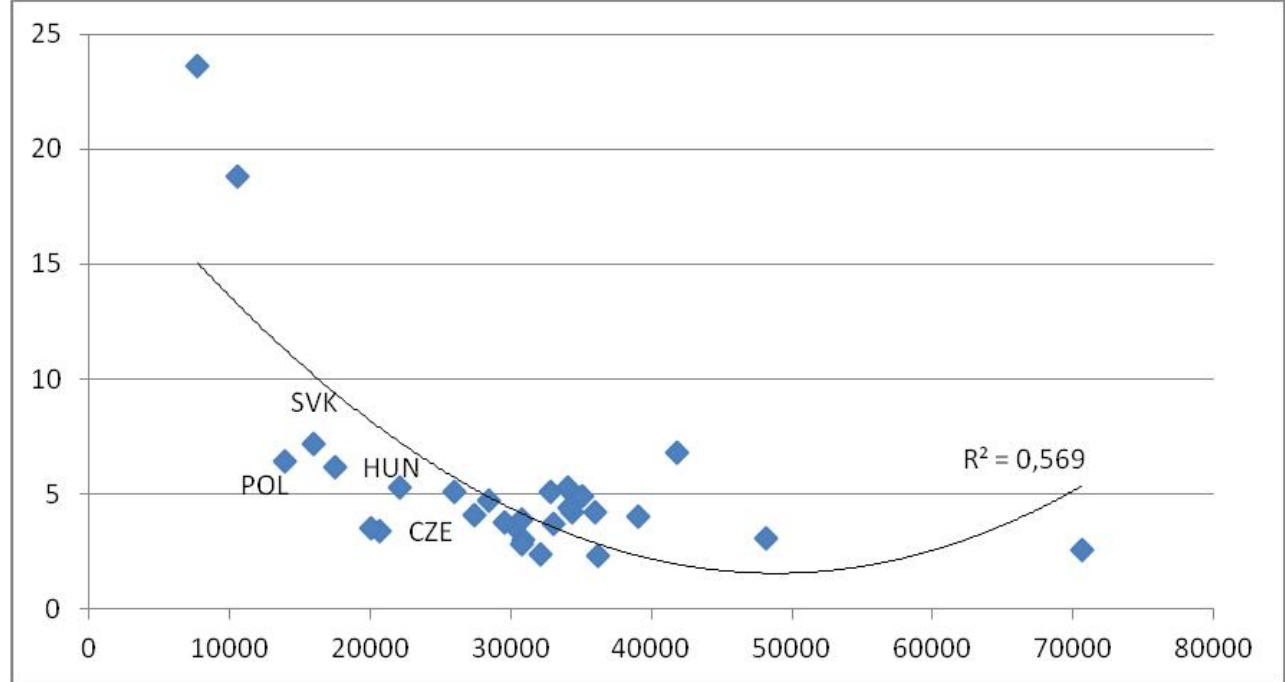

Source: modified from Leigh A., Jencks Ch., Smeeding T. (2009). 
The efficiency measure obtained for Poland's healthcare system is 1, i.e. the system is efficient, and recommendations are null, as no changes of inputs are required given the current outputs.

Table 3: Optimal inputs and outputs (following benchmark), 2004.

\begin{tabular}{|c|c|c|c|c|c|c|c|c|}
\hline Country & Score & $\begin{array}{c}\text { \%GDP } \\
\{I\}\end{array}$ & $\begin{array}{l}\text { Phys } \\
\{I\}\end{array}$ & $\begin{array}{c}\text { Beds } \\
\{I\}\end{array}$ & $\begin{array}{c}\text { Cancers } \\
\{\mathbf{O}\}\end{array}$ & $\begin{array}{l}\text { CVD } \\
\{O\}\end{array}$ & $\begin{array}{c}\mathbf{E} \\
\{\mathbf{O}\}\end{array}$ & $\begin{array}{c}\text { HLY } \\
\{O\}\end{array}$ \\
\hline & & 6.38617 & 57.326 & 419.316 & 93636 & & 0.88413 & \\
\hline Belgium & 84697 & 8.19869 & 242.937 & 451.713 & 0.61996 & 0.93341 & 0.89445 & 0.79354 \\
\hline Bulgaria & 1 & 7.31 & 352.21 & 613.13 & .74367 & 0 & 0.17015 & 0.92244 \\
\hline Cyprus & 1 & 6.42 & 268.39 & 420 & 1 & 0.88914 & 0.91232 & 0.47922 \\
\hline Czech Rep. & 0.69527 & 4.79739 & 144.035 & 239.417 & 0.36110 & 0.55403 & 0.52088 & 0.47922 \\
\hline Denmark & 1 & 9.67 & 322.24 & 397.36 & 0.37533 & 0.91473 & 0.73173 & 1 \\
\hline Estonia & 0.55971 & 2.8713 & 120.035 & 187.842 & 0.44724 & 0.39766 & 0.40803 & 0.21433 \\
\hline Finland & 0.94576 & 6.86619 & 244.991 & 492.254 & 0.83441 & 0.85379 & 0.8843 & 0.53459 \\
\hline Germany & 0.68228 & 7.27992 & 231.327 & 551.025 & 0.72578 & 0.83958 & 0.87578 & 0.58172 \\
\hline Greece & 1 & 8.68 & 487.65 & 468.92 & 0.70457 & 0.72476 & 0.84238 & 0.90305 \\
\hline Hungary & 0.34642 & 2.84757 & 115.597 & 181.751 & 0.42 & 0.38764 & 0.39485 & 0.21994 \\
\hline Latvia & 0.45049 & 2.93267 & 122.601 & 191.857 & 0.45680 & 0.40616 & 0.41675 & 0.21891 \\
\hline Lithuania & & 3.0655 & 128.154 & 200.546 & 0.47749 & 0.42456 & 0.43562 & 0.22883 \\
\hline Luxembourg & 1 & 8.2 & 242.3 & 639.37 & 0.71542 & 0.9035 & 0.94676 & 0.66482 \\
\hline Netherlands & 0.92404 & 8.36568 & 244.667 & 408.935 & 0.58528 & 0.95342 & 0.88980 & 0.84960 \\
\hline Poland & 1 & 6.2 & 229.02 & 666.84 & 0.33381 & 0.56333 & 0.41962 & 0.75900 \\
\hline Portugal & 0.93994 & 8.34488 & 308.565 & 337.356 & 0.75722 & 0.90174 & 0.95069 & 0.70539 \\
\hline Slovakia & 0.45151 & 3.25541 & 131.401 & 265.479 & 0.37854 & 0.37252 & 0.35595 & 0.30748 \\
\hline Slovenia & 0.89103 & 7.00086 & 204.751 & 342.219 & 0.48979 & 0.79787 & 0.74464 & 0.71099 \\
\hline Spain & 1 & 8.22 & 346.28 & 341.7 & 0.68888 & 1 & 0.99061 & 0.72022 \\
\hline Sweden & 1 & 9.09 & 344.76 & 301.19 & 0.75037 & 0.91159 & 1 & 0.74792 \\
\hline UK & 1 & 7.91 & 231.34 & 386.66 & 0.5534 & 0.901487 & 0.841336 & 0.803324 \\
\hline
\end{tabular}

Source: own elaboration using Eurostat data and MaxDEA 6.3.mdb software.

Poland is the only efficient country in the group of transition states as a result of small healthcare expenditures and relatively good condition of health. It is worth noting that Estonia, Hungary and Slovenia can significantly improve their health effects given current inputs, and even at reduced inputs. There are efficient healthcare systems in Bułgaria (BCR), Cypr $(\mathrm{BV}, \mathrm{c})$, Denmark (BV, 1), Greece (BV, c), Luxembourg (BC, o), Poland (BCR), Spain $(\mathrm{BV}, \mathrm{c})$, Sweden $(\mathrm{BV}, 1)$, UK $(\mathrm{BV}, \mathrm{c})$. They are mostly financed according to Beveridge system. 
Table 4: Recommendations (Table 3 cont.), 2004

\begin{tabular}{|c|c|c|c|c|c|c|c|}
\hline Country & $\begin{array}{c}\% \text { GDP } \\
\{I\}\end{array}$ & $\begin{array}{l}\text { Phys } \\
\{I\}\end{array}$ & $\begin{array}{c}\text { Beds } \\
\{I\}\end{array}$ & $\begin{array}{c}\text { Cancers } \\
\{\mathbf{O}\}\end{array}$ & $\begin{array}{c}\text { CVD } \\
\{0\}\end{array}$ & $\begin{array}{c}\mathbf{E} \\
\{\mathbf{O}\}\end{array}$ & $\begin{array}{c}\text { HLY } \\
\{\mathbf{O}\}\end{array}$ \\
\hline Austria & -4.04384 & -162.944 & -299.969 & 0.297704 & 0.012105 & 0 & 0 \\
\hline Belgium & -1.48131 & -43.8929 & -114.364 & 0 & 0 & 0.043717 & 0.12872 \\
\hline Bulgaria & 0 & 0 & 0 & 0 & 0 & 0 & 0 \\
\hline Cyprus & 0 & 0 & 0 & 0 & 0 & 0 & 0 \\
\hline Czech Rep. & -2.10261 & -107.2 & -232.881 & 0.141656 & 0.056149 & 0 & 0 \\
\hline Denmark & 0 & 0 & 0 & 0 & 0 & 0 & 0 \\
\hline Estonia & -2.2587 & -141.457 & -250.936 & 0 & 0.065565 & 0.27024 & 0.21433 \\
\hline Finland & -0.44528 & -14.0494 & -38.5045 & 0 & 0 & 0.047138 & 0.437639 \\
\hline Germany & -3.39008 & -107.723 & -272.582 & 0.076858 & 0.014016 & 0 & 0.34349 \\
\hline Greece & 0 & 0 & 0 & 0 & 0 & 0 & 0 \\
\hline Hungary & -5.37243 & -218.093 & -515.524 & 0.42 & 0 & 0.179816 & 0.05928 \\
\hline Latvia & -3.57733 & -160.331 & -434.901 & 0 & 0.227481 & 0.416749 & 0.127498 \\
\hline Lithuania & -2.6045 & -166.583 & -347.543 & 0 & 0.111198 & 0.322889 & 0.082011 \\
\hline Luxembourg & 0 & 0 & 0 & 0 & 0 & 0 & 0 \\
\hline Netherlands & -0.75733 & -20.1128 & -33.9658 & 0.089025 & 0 & 0.007758 & 0.068439 \\
\hline Poland & 0 & 0 & 0 & 0 & 0 & 0 & 0 \\
\hline Portugal & -0.60355 & -19.7148 & -21.5543 & 0 & 0 & 0.170942 & 0.289877 \\
\hline Slovakia & -3.95459 & -172.526 & -378.187 & 0 & 0.012402 & 0 & 0 \\
\hline Slovenia & -0.92294 & -25.0391 & -52.2946 & 0.04776 & 0 & 0.081798 & 0.273321 \\
\hline Spain & 0 & 0 & 0 & 0 & 0 & 0 & 0 \\
\hline Sweden & 0 & 0 & 0 & 0 & 0 & 0 & 0 \\
\hline UK & 0 & 0 & 0 & 0 & 0 & 0 & 0 \\
\hline
\end{tabular}

Source: own elaboration using Eurostat data and MaxDEA 6.3.mdb software.

When analyzing the suitability of DEA application to evaluating national healthcare systems, a significant uncertainty emerges as we expect positive coefficients of correlation between inputs and outputs (including mortalities transposed to stimulants). The coefficients of Pearson correlation between the number of beds and the outputs are problematic (table 5). As previously mentioned, the most advanced medical technology results in significantly shorter inpatient stay, hence the number of hospital beds declines. Therefore, among other things, recommendations include the reduction of beds in order to improve medical treatment effects, that implies the adoption of the most recent medical technologies in health services.

Table 6 presents the efficiency measures of healthcare systems in the countries under study in 2004 and 2012 [Biernacki, 2013]. Estonia, Hungary and Slovakia improved their efficiency in health services in this period. The Czech Republic and Poland worsened their efficiency measures, whereas the Czech Republic improved their efficiency measured by HLY and 
Poland deteriorated (cf. tables 1 and 2). Nevertheless, Poland's healthcare system outperforms other transition countries.

Table 5: Coefficients of correlation between inputs (I) and outputs (O), 2004

\begin{tabular}{lcccc}
\hline \multicolumn{1}{c}{2004} & $\begin{array}{c}\text { Cancers } \\
\{\mathbf{O}\}\end{array}$ & $\begin{array}{c}\text { CVD } \\
\{\mathbf{O}\}\end{array}$ & $\begin{array}{c}\mathbf{E} \\
\{\mathbf{O}\}\end{array}$ & $\begin{array}{c}\text { HLY } \\
\{\mathbf{O}\}\end{array}$ \\
\hline \%GDP $\{\mathrm{I}\}$ & 0.204981 & 0.653502 & 0.677201 & 0.343614 \\
\hline PPP $\{\mathrm{I}\}$ & 0.320289 & 0.752185 & 0.774945 & 0.357608 \\
\hline Phys $\{\mathrm{I}\}$ & 0.041545 & -0.17595 & -0.03765 & 0.067787 \\
\hline Beds $\{\mathrm{I}\}$ & -0.37528 & -0.4916 & -0.4737 & -0.55338 \\
\hline
\end{tabular}

Source: own elaboration using Eurostat data.

Table 6: Comparison of efficiency of national healthcare systems

\begin{tabular}{lccc}
\hline \multicolumn{1}{c}{ Country } & $\mathbf{2 0 0 4}$ & I/2012 & II/2012 \\
\hline Czech Republic & 0.69527 & 0.8581 & 0.5440 \\
\hline Estonia & 0.55971 & 1.0000 & 0.6154 \\
\hline Finland & 0.94576 & 0.9054 & 0.7536 \\
\hline Germany & 0.68228 & 0.7267 & 0.5652 \\
\hline Hungary & 0.34642 & 0.7970 & 0.6274 \\
\hline Poland & 1.0000 & 1.0000 & 0.8787 \\
\hline Portugal & 0.93994 & 1.0000 & 0.5288 \\
\hline Slovak Republic & 0.45151 & 0.9981 & 0.6226 \\
\hline Spain & 1.0000 & 1.0000 & 0.5886 \\
\hline Sweden & 1.0000 & 1.0000 & 0.5619 \\
\hline United Kingdom & 1.0000 & 1.0000 & 0.7536 \\
\hline
\end{tabular}

Source: own elaboration based on data from http://ec.europa.eu/eurostat/web/products-datasets/-/tps00152

Column 3 presents the measures of efficiency after removing the number of beds from inputs because of its negative correlation with medical treatment effects.

\section{Conclusion}

Healthcare systems in the European Union financed according to Beveridge are more efficient than Bismarck systems adopted by all transition countries following 1990. As recommended by the results of MaxDEA6.3.mdb software, relevant reductions of inputs are proposed so as to improve the efficiency of national healthcare systems in transformed economies, given the current health effects, and in some cases to enhance them, in particular to extend life expectancy and to lessen mortality caused by cancers and cardiovascular diseases.

In Poland, Czech Republic and Slovakia healthcare system is based on the public funding which is derived from compulsory health insurances. In this countries $30 \%$ of total healthcare 
costs are derived from the households. It is one of the highest value in Europe. However, the availability and the quality of the healthcare services are not the best.

According to the WHO, a social state of health is a responsibility of healthcare system "whose primary purpose is to promote, restore or maintain health". Health of individuals depends also on other factors such as genetic make-up, behaviors and lifestyle, environment (economic, social, cultural and physical environment), and organization of healthcare system. Badura (1995) presented the estimated shares of those factors influencing mortality caused by various illnesses. In the case of cardiovascular diseases the distribution was as follows: biology $-25 \%$, environment $-9 \%$, lifestyle $54 \%$, and healthcare $-12 \%$; in the case of cancers: $29 \%, 24 \%, 37 \%$ and $10 \%$, respectively. Badura's estimates were based on data from the $1990 \mathrm{~s}$, nevertheless the impact of healthcare system and its efficiency on population health remains considerable, even if not decisive.

\section{References}

[1] Badura B., 1995, What is and what determines health, in: Laaser U., ed., Scientific Foundations for a Public Health Policy in Europe, Juventa Verlag, Weinheim.

[2] Biernacki M., 2013, Ocena efektywności instytucji publicznych w sektorach edukacji i ochrony zdrowia [Evaluating the efficiency of public institutions in sectors of education and healthcare], Wydawnictwo Uniwersytetu Ekonomicznego we Wrocławiu.

[3] Charnes A., Cooper W., Rhodes E., 1978, Measuring the efficiency of decision making units, "European Journal of Operational Research" 2(6), pp. 429-444.

[4] Kautsch M., Klich J., Whitfeld M., 2001, Zarządzanie w opiece zdrowotnej [Management in Healthcare], Wydawnictwo Uniwersytetu Jagiellońskiego, Kraków.

[5] Leigh A., Jencks Ch., Smeeding T., 2009, Health and Economic Inequality, The Oxford Handbook of Economic Inequality.

[6] Niżnik J., 2004, W poszukiwaniu racjonalnego systemu finansowania ochrony zdrowia [Seeking a Rational System of Healthcare Financing], Oficyna Wydawnicza Branta, Bydgoszcz-Kraków. 
20th International Scientific Conference AMSE

Applications of Mathematics and Statistics in Economics 2017

Szklarska Poręba, Poland

30 August 2017 - 3 September 2017 